\title{
Nitrogen Dynamics of Cole Crop Production: Implications for Fertility Management and Environmental Protection
}

\author{
Richard Smith and Michael Cahn \\ University of California Cooperative Extension, 1432 Abbott Street, Salinas, \\ CA 93901
}

Timothy Hartz ${ }^{1}$

Department of Plant Sciences, University of California, One Shields Avenue, Davis, CA 95616

\section{Patricia Love and Barry Farrara \\ University of California Cooperative Extension, 1432 Abbott Street, Salinas, CA 93901}

Additional index words. nitrate leaching, partial $\mathrm{N}$ balance, rooting depth, irrigation efficiency, crop residue

\begin{abstract}
Intensive production of cool-season vegetables has contributed to nitrate pollution of groundwater along the central coast of California. Broccoli (Brassica oleracea L. var. italica), cabbage (Brassica oleracea L. var. capitata), and cauliflower (Brassica oleracea L. var. botrytis) are important crops in this region, but few data are available regarding the nitrogen dynamics of these cole crops under current production practices, and whether those practices are protective of groundwater. Monitoring was conducted in 14 commercial broccoli, 8 cabbage, and 8 cauliflower fields evaluating crop growth, rooting depth, $N$ uptake and partitioning, patterns of soil $\mathbf{N}$ availability, and current $\mathbf{N}$ fertilization and irrigation practices. Aboveground biomass $N$ at harvest averaged 367,367 , and $319 \mathrm{~kg} \cdot \mathrm{ha}^{-1}$ for broccoli, cabbage, and cauliflower, respectively, with mean $N$ fertilization rates of 209,280 , and $256 \mathrm{~kg} \cdot \mathrm{ha}^{-1}$. The relatively small fraction of biomass $\mathrm{N}$ removed at harvest with cauliflower $(23 \%)$ and broccoli $(31 \%)$ resulted in a low partial $N$ balance $(\mathrm{PNB})$ of $30 \%$ and $57 \%$, respectively, compared with cabbage (PNB of 70\%). Rooting depth increased throughout the growing season, reaching $\approx 1 \mathrm{~m}$ by harvest, with about $70 \%$ of roots located in the top $40 \mathrm{~cm}$ in all crops. Soil mineral $\mathrm{N}$ (SMN; 0- to 30-cm depth) varied among fields, with the early-season median value of $18 \mathrm{mg} \cdot \mathrm{kg}^{-1}$ declining to $5 \mathrm{mg} \cdot \mathrm{kg}^{-1}$ by harvest. Seasonal $\mathrm{N}$ application was not correlated with early-season SMN. Irrigation applied, predominately through sprinklers, averaged $>\mathbf{2 0 0} \%$ of estimated crop evapotranspiration. Substantial $N$ mineralization from broccoli residue was observed within 2-3 months following fall incorporation, with potential $\mathrm{NO}_{3}-\mathrm{N}$ leaching losses exceeding $100 \mathrm{~kg} \cdot \mathrm{ha}^{-1}$ in both monitored fields. We conclude that improved irrigation management, adjusting $N$ rates based on residual $S M N$, and employing a remediation practice such as cover cropping to limit winter $\mathrm{NO}_{3}-\mathrm{N}$ leaching losses could substantially improve $\mathbf{N}$ efficiency in cole crop production.
\end{abstract}

The Salinas Valley along the central coast of California produces more than 100,000 ha of cool-season vegetables per year. The mild Mediterranean climate allows an extended growing season, and production of two to three crops per year is the norm. With little precipitation during the main production season (March-November), frequent irrigation is required. Fields are typically fallow during the winter when most of the annual precipitation occurs. This intensive production system has

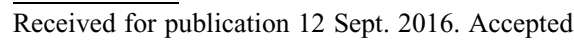
for publication 14 Oct. 2016.

This research was supported by the California Department of Food and Agriculture Fertilizer Research and Education Program.

${ }^{1}$ Corresponding author. E-mail: tkhartz@ucdavis. edu. led to serious environmental problems. Nitrate contamination of groundwater has become widespread; it has been estimated that $\mathrm{NO}_{3}-\mathrm{N}$ loading to groundwater exceeds $100 \mathrm{~kg} \cdot \mathrm{ha}^{-1} \cdot \mathrm{yr}^{-1}$ (Rosenstock et al., 2014). Additionally, excessive extraction of groundwater for irrigation has resulted in significant seawater intrusion, endangering aquifers used for both irrigation and urban needs (Harter, 2015).

Extensive research has been conducted to improve $\mathrm{N}$ fertilization and irrigation management of lettuce (Lactuca sativa L.), the predominant crop in this region (Bottoms et al., 2012; Breschini and Hartz, 2002; Hartz et al., 2000; Jackson et al., 1994). Less attention has been given to cole crops (broccoli, cabbage, and cauliflower), which are important rotational crops. Cole crops represent both an opportunity and a challenge. They are relatively deep rooted
(Greenwood et al., 1982; Thorup-Kristensen, 2001), have the ability to take up more than $300 \mathrm{~kg} \mathrm{~N} /$ ha (Bakker et al., 2009b; Bowen et al., 1999; Thompson et al., 2002a), and consequently may be able to scavenge residual SMN from a substantial depth. Conversely, a large amount of $\mathrm{N}$ is contained in crop residue after harvest, and rapid mineralization from this $\mathrm{N}$-rich residue has been recognized as a nitrate leaching hazard (Bakker et al., 2009b; Congreves and Van Eerd, 2015; Everaarts, 2000).

Yield-maximizing $\mathrm{N}$ fertilization rates for cole crops have been reported to range from $<150$ to $>400 \mathrm{~kg} \cdot \mathrm{ha}^{-1}$ (Bakker et al., 2009a; Bowen et al., 1999; Cutcliffe and Munro, 1976; Kahn et al. 1991; Sorenson, 1999; Thompson et al., 2000a, 2002a; Zebarth et al., 1991). This wide range undoubtedly reflects differences among studies in field environment, soil fertility, plant population, and yield potential. Residual SMN has been recognized as a major determinant of the $\mathrm{N}$ fertilizer requirement of cole crops (Bakker et al., 2009b; Everaarts and van den Berg, 1996; Heckman et al., 2002; Zebarth et al., 1995). In an intensive production system like that of the Salinas Valley, where high levels of residual SMN are common (Bottoms et al., 2012; Breschini and Hartz, 2002), efficient $\mathrm{N}$ management requires consideration of field-specific factors rather than prescriptive recommendations.

Irrigation management is closely linked to $\mathrm{N}$ efficiency in cole crop production (Thompson et al., 2000b, 2002b). Marketable yield is maximized by maintaining relatively low soil moisture tension (10-25 kPa; Smittle et al., 1994; Thompson et al., 2000a, 2002a), but irrigation in excess of crop evapotranspiration $\left(\mathrm{ET}_{\mathrm{c}}\right)$ can result in significant $\mathrm{NO}_{3}-\mathrm{N}$ leaching in heavily fertilized fields. Documentation is lacking on cole crop irrigation requirements under coastal California conditions, and on current irrigation practices.

Improved cole crop $\mathrm{N}$ management requires a more complete understanding of soil and crop $\mathrm{N}$ dynamics of these crops within the intensive crop production scheme of this region. This study was undertaken to document cole crop growth, rooting depth, $\mathrm{N}$ uptake and partitioning, and patterns of soil $\mathrm{N}$ availability in representative commercial fields of the Salinas Valley.

\section{Materials and Methods}

Monitoring sites. Crop growth and N uptake was monitored in a total of 30 commercial cole crop fields ( 14 broccoli, 8 cabbage, and 8 cauliflower) in 2012 and 2013. All fields were located in the Salinas Valley of California (approximate lat. $36^{\circ} 41^{\prime}$, long. $121^{\circ} 39^{\prime}$ ), and were grown during the main production season (March-November). Field locations represented both the cooler coastal area (production season mean temperature $\approx 12{ }^{\circ} \mathrm{C}$ ) and the warmer inland region (production season mean temperature $\approx 14{ }^{\circ} \mathrm{C}$ ). Soil texture ranged among fields from sandy loam to clay, whereas soil organic matter varied from $1.2 \%$ to $4.2 \%$, averaging $2.5 \%$. Soil $\mathrm{pH}$ ranged from 
Table 1. Crop nitrogen dynamics in broccoli, cabbage, and cauliflower production; values represent the means of 14 broccoli, 8 cabbage, and 8 cauliflower fields. Data on biomass or biomass $\mathrm{N}$ refer to aboveground biomass only.

\begin{tabular}{|c|c|c|c|c|c|c|c|c|}
\hline \multirow[b]{2}{*}{ Crop } & \multirow[b]{2}{*}{ Days to harvest } & \multirow[b]{2}{*}{$\begin{array}{l}\text { Biomass } \\
\left({\left.\mathrm{Mg} \cdot \mathrm{ha}^{-1}\right)}\right.\end{array}$} & \multicolumn{3}{|c|}{$\mathrm{kg} \cdot \mathrm{ha}^{-1}$} & \multirow[b]{2}{*}{$\begin{array}{c}\text { Harvest } \mathrm{N} \text { removal } \\
(\% \text { of biomass } \mathrm{N})\end{array}$} & \multirow[b]{2}{*}{ Partial N balance ${ }^{\mathrm{z}}(\%)$} & \multirow[b]{2}{*}{ Residue N $\left(\mathrm{g} \cdot \mathrm{kg}^{-1}\right)$} \\
\hline & & & $\begin{array}{c}\mathrm{N} \text { fertilizer } \\
\text { applied }\end{array}$ & Biomass N & $\begin{array}{l}N \text { removal } \\
\text { in harvest }\end{array}$ & & & \\
\hline Broccoli & $84 \pm 2^{\mathrm{y}}$ & $9.6 \pm 0.3$ & $209 \pm 12$ & $367 \pm 18$ & $113 \pm 7$ & $31 \pm 1$ & $57 \pm 4$ & $34.9 \pm 1.8$ \\
\hline Cabbage & $79 \pm 4$ & $12.5 \pm 0.9$ & $280 \pm 13$ & $367 \pm 15$ & $193 \pm 11$ & $53 \pm 2$ & $70 \pm 4$ & $33.5 \pm 2.1$ \\
\hline Cauliflower & $73 \pm 2$ & $7.7 \pm 0.3$ & $256 \pm 20$ & $319 \pm 9$ & $75 \pm 7$ & $23 \pm 2$ & $30 \pm 3$ & $41.8 \pm 1.4$ \\
\hline
\end{tabular}

${ }^{\mathrm{z}} \mathrm{N}$ removed in harvest/fertilizer $\mathrm{N}$ applied.

$\mathrm{y}_{ \pm \text {SE of measurement. }}$

6.1 to 7.9 , averaging 7.4. Cooperating growers provided $\mathrm{N}$ fertilization records.

Raised soil beds of either 1 or $2 \mathrm{~m}$ width were used, with two to five rows (broccoli or cabbage) or one to three rows (cauliflower) of plants per bed. All cauliflower fields were transplanted, while both transplanted and direct-seeded broccoli and cabbage fields were included. Planting dates ranged from 18 Mar. to 3 Sept., with harvest between 16 June and 26 Nov. Plant population ranged from 102,000 to 158,000 per hectare (broccoli), 52,000 to 84,000 per hectare (cabbage), and 33,000 to 56,000 per hectare (cauliflower). Sprinkler irrigation was used for crop establishment in all fields, with two broccoli and three cauliflower fields converted to drip irrigation following establishment.

Crop and soil $N$ dynamics. Biomass samples were collected three to five times during the crop cycle from each field. On each evaluation date, the aboveground biomass of three to 10 plants (depending on growth stage) was collected from each of three or four representative areas per field. Tissue was oven-dried at $65{ }^{\circ} \mathrm{C}$, reweighed, and dry biomass was calculated. Dry tissue was ground to pass a $0.4-\mathrm{mm}$ mesh and total $\mathrm{N}$ concentration was determined using an $\mathrm{N}$ gas analyzer (model FP-528; LECO Corp., St. Joseph, MI). At commercial maturity, aboveground crop biomass was divided into harvestable material and crop residue, with the dry biomass and $\mathrm{N}$ concentration of each tissue type determined separately.

Soil sampling for determination of SMN was done concurrently with each biomass sampling. Composite samples of ten 2-cmdiameter soil cores were collected from each biomass sampling area. In 2012, soil sampling was confined to the top 30-cm depth; samples from 30- to 60-cm depth were also collected in nine broccoli fields sampled in 2013. Fieldmoist soil was extracted in $2 \mathrm{~N} \mathrm{KCl}$, and $\mathrm{NO}_{3}-\mathrm{N}$ and $\mathrm{NH}_{4}-\mathrm{N}$ concentration were determined by the colorimetric procedures of Knepel (2003) and Hofer (2003), respectively.

Evaluation of rooting depth was conducted multiple times over the growing season in each of 10 broccoli, 8 cabbage, and 5 cauliflower fields. On each evaluation date, three pits were dug to determine the depth of the deepest root at that growth stage. In three broccoli, two cauliflower, and one cabbage field, more intensive root sampling was done at commercial harvest to document root density by soil depth. In each field, one pit was dug the width of one bed and $1 \mathrm{~m}$ deep. A smooth face was prepared on the excavated

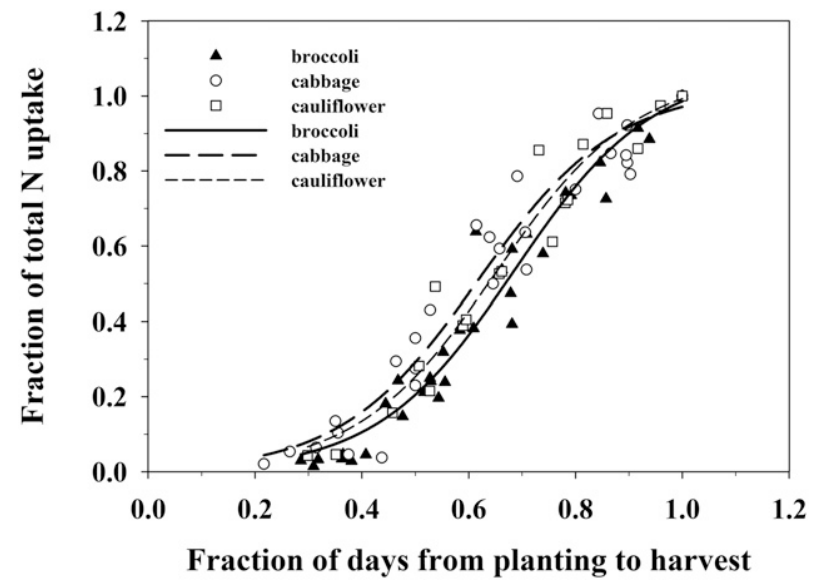

Fig. 1. Aboveground $\mathrm{N}$ uptake in broccoli, cabbage, and cauliflower as a function of time after planting; model parameters given in Table 1 .

area and a hand-pressurized sprayer was used to wash soil from exposed roots. The number of roots in each $20-\mathrm{cm}$ depth increment was determined.

Irrigation monitoring. To evaluate the efficiency of current irrigation practices, the seasonal irrigation volume applied was monitored in 10 broccoli, 7 cabbage, and 6 cauliflower fields using magnetic flowmeters ( $\mathrm{Ag} 2000$; Seametric Inc., Kent, WA) positioned on the main irrigation lines. The flowmeters were interfaced with data loggers (CR1000; Campbell Sci. Inc., Logan, UT) to record the date, time, and volume of each irrigation event. $\mathrm{ET}_{\mathrm{c}}$ was estimated for each monitored field by multiplying daily reference evapotranspiration data collected from the nearest California Irrigation Management Information System weather station by daily crop coefficients $\left(K_{\mathrm{c}}\right)$. Daily $K_{\mathrm{c}}$ was estimated as described in Johnson et al. (2016):

$$
K_{\mathrm{c}}=\max \left(K_{\mathrm{e}}, T\right)
$$

where $K_{\mathrm{e}}$ was a soil evaporation coefficient based on the method of Gallardo et al. (1996) and $T$ was a transpirational coefficient derived from crop canopy cover. Early in the crop cycle when canopy cover and transpiration were low, $K_{\mathrm{e}}$ dominated and was used as the $K_{\mathrm{c}}$; on any day that $T$ was greater than $K_{\mathrm{e}}$, $T$ was used as the $K_{\mathrm{c}}$.

Images taken by a digital camera (Rebel T5i 700D 18.1 Megapixel; Canon Inc., Melville, NY), modified to take normalized difference vegetated index images (LDP-LLC MaxMax Inc., Carlstadt, NJ), were used to estimate canopy cover. Images were taken at a $3 \mathrm{~m}$ height every 2 weeks. Fractional canopy cover was determined from the images using PixelWrench 2 software (Tetracam Inc. Chatsworth, CA). Canopy cover data were fit to an equation modified from Gallardo et al. (1996):

$$
\begin{aligned}
& \text { Canopy cover }(\%) \\
& =\operatorname{Gmax} /(1+\exp [A+B \times \text { day } \\
& \quad /(\text { Maxday } \times \text { Fmax })]
\end{aligned}
$$

where Gmax is the maximum canopy cover, $A$ and $B$ are fitted parameters, day is the number of days after planting or transplanting, Maxday is the total days between planting and harvest, and Fmax is the fraction of the crop cycle when the maximum canopy size is achieved. Parameters for this model were determined separately for broccoli, cabbage, and cauliflower. These models were used to calculate the daily $T$ value using the equation [(adapted from Johnson et al. (2016)]:

$$
T=\left(1.5 C-0.0039 C^{2}\right) / 100
$$

where $C$ is percent canopy cover estimated in Eq. [2].

Fate of residue $N$ and residual SMN. SMN was monitored over $\approx 4$ months following crop residue incorporation in two broccoli fields of loam soil texture harvested in Fall 2014. To evaluate the contribution of decaying crop residue to SMN, all aboveground residue was removed from three $12 \times$ $12 \mathrm{~m}$ areas in each field before residue incorporation. Soil samples (composites of 10 cores) were collected on intervals of $\approx 14 \mathrm{~d}$ from each of these areas, and from adjacent areas where crop residue had been incorporated. The field-moist samples, collected from 0 - to $30-\mathrm{cm}$ and $30-$ to $60-\mathrm{cm}$ depths, were 
extracted in $2 \mathrm{~N} \mathrm{KCl}$ for determination of $\mathrm{NH}_{4}$ $\mathrm{N}$ and $\mathrm{NO}_{3}-\mathrm{N}$ concentration as previously described.

Data analysis and statistics. The parameters $A$ and $B$ of Eq. [2] were determined for each crop type by linear regression of $\ln [(\mathrm{Gmax} /$ canopy) - 1] vs. (day/Maxdays) using Excel software (Microsoft, Redmond, WA). Data were fit to Eq. [4] using the SigmaPlot 12.5 nonlinear regression analysis tool (Systat Software Inc., San Jose, CA). The change in rooting depth over the season was compared among crops using the linear regression procedure (PROC REG) in Statistical Analysis Software (SAS Institute Inc., Cary, NC). An F-test was performed that compared a full model with separate slopes for each crop type to a reduced model which included one slope for all crop types.

\section{Results and Discussion}

The length of the growing season was shortest for cauliflower (mean of $73 \mathrm{~d}$ from transplant to harvest) and longest for broccoli (mean of $84 \mathrm{~d}$ from transplant or seeding to harvest; Table 1). Transplanting broccoli and cabbage reduced the growing season length by an average of $10 \mathrm{~d}$ compared with direct seeding. Cabbage accumulated the most aboveground dry biomass (mean of 12.5 $\left.\mathrm{Mg} \cdot \mathrm{ha}^{-1}\right)$, cauliflower the least $\left(7.7 \mathrm{Mg} \cdot \mathrm{ha}^{-1}\right)$. Mean aboveground biomass $\mathrm{N}$ was more than $300 \mathrm{~kg} \cdot \mathrm{ha}^{-1}$ for all crops. $\mathrm{N}$ removal in harvest varied substantially among crops, ranging from $53 \%$ of aboveground biomass $\mathrm{N}$ (cabbage) to only $31 \%$ and $23 \%$ of biomass $\mathrm{N}$ for broccoli and cauliflower, respectively. Aboveground residue $\mathrm{N}$ content averaged 254 (broccoli), 244 (cauliflower), and $174 \mathrm{~kg} \cdot \mathrm{ha}^{-1}$ (cabbage). The residue of all crops averaged $>33 \mathrm{~g} \cdot \mathrm{kg}^{-1} \mathrm{~N}$, suggesting the likelihood of rapid $\mathrm{N}$ mineralization upon soil incorporation (Congreves and Van Eerd, 2015; De Neve and Hoffman, 1996).

Seasonal $\mathrm{N}$ fertilization rates varied substantially among fields and crops, whereas in all but three fields fertilizer $\mathrm{N}$ application was less than the aboveground biomass $\mathrm{N}$ accumulation. Biomass $\mathrm{N}$ uptake exceeded fertilizer $\mathrm{N}$ application by an average of 158,87 , and 63 $\mathrm{kg} \cdot \mathrm{ha}^{-1}$ for broccoli, cabbage, and cauliflower, respectively. However, given the small fraction of biomass $\mathrm{N}$ removed with harvested material, the PNB ( $\mathrm{N}$ removed in harvest/fertilizer $\mathrm{N}$ applied) was low for cauliflower $(30 \%)$, and higher for broccoli (57\%) and cabbage (70\%). Individual fields reached a PNB as high as $45 \%, 78 \%$, and $88 \%$ for cauliflower, broccoli, and cabbage, respectively.

The pattern of $\mathrm{N}$ uptake fit a sigmoidal function (Fig. 1) described by the equation:

$$
\begin{aligned}
& \text { N uptake }\left(\mathrm{kg} \cdot \mathrm{ha}^{-1}\right) \\
& =a \times N_{\max } /(1 \\
& \left.\quad+\exp \left[\left(-(\text { day/Maxday })-Y_{o}\right) / b\right]\right)
\end{aligned}
$$

where $N_{\max }$ is the amount of $\mathrm{N}\left(\mathrm{kg} \cdot \mathrm{ha}^{-1}\right)$ the crop accumulates in aboveground biomass at harvest; $a, b$, and $Y_{o}$ are fitted parameters; day is the number of days after planting; and
Maxday is the average length of the crop cycle, calculated as the days between planting and harvest. Equation [4] was adapted from Willcutts et al. (1998), where $\mathrm{N}$ uptake is a function of time rather than applied $\mathrm{N}$. Fitted parameters for Eq. [4] are summarized in Table 2. During the rapid N uptake phase (from roughly $40 \%$ to $90 \%$ of the time from planting to harvest) aboveground biomass $\mathrm{N}$ increased by an average of $\approx 7 \mathrm{~kg} \cdot \mathrm{ha}^{-1} \cdot \mathrm{d}^{-1}$ for all crops.

Although no fertilizer $\mathrm{N}$ rate comparisons were conducted in these fields, it can be assumed that $\mathrm{N}$ supply was generally adequate for maximum growth. Greenwood et al. (1996) proposed a model for the critical $\mathrm{N}$ concentration of cole crops $\left(N_{c}\right.$, the minimum whole plant $\mathrm{N}$ concentration required to maximize growth):

$$
\begin{aligned}
& N_{c}\left(\mathrm{~g} \cdot \mathrm{kg}^{-1}\right) \\
& \quad=52-1.78 \times \operatorname{dry} \operatorname{mass}\left(\mathrm{Mg} \cdot \mathrm{ha}^{-1}\right)
\end{aligned}
$$

The data of Vagen et al. (2004) supported the validity of this model for broccoli. Most broccoli and cauliflower fields in the present study maintained whole plant $\mathrm{N}$ concentration above this $N_{c}$ curve (Fig. 2). The comparison of observed biomass $\mathrm{N}$ accumulation with critical $\mathrm{N}$ uptake $\left(N_{\text {upt }}\right.$, the minimum $\mathrm{N}$ uptake required to maintain whole plant $\mathrm{N}$

\begin{tabular}{|c|c|c|c|c|c|c|c|}
\hline & & & & Biomass $\mathrm{N}$ at harvest & Days to harvest & & \\
\hline Crop & $a$ & $b$ & $Y_{o}$ & $N_{\max }$ & Maxday & $R^{2}$ & $P$ value \\
\hline Broccoli & 1.0582 & 0.1231 & 0.6748 & 367 & 84 & 0.97 & $<0.001$ \\
\hline Cabbage & 1.0258 & 0.1338 & 0.6138 & 367 & 79 & 0.96 & $<0.001$ \\
\hline Cauliflower & 1.0575 & 0.1244 & 0.6725 & 319 & 73 & 0.94 & $<0.001$ \\
\hline
\end{tabular}
above $N_{c}$, calculated from Eq. [5], suggested that a substantial amount of luxury $\mathrm{N}$ uptake occurred in some broccoli and cauliflower

Table 2. Model parameters (Eq. [4]) describing the pattern of $\mathrm{N}$ uptake of cole crops.

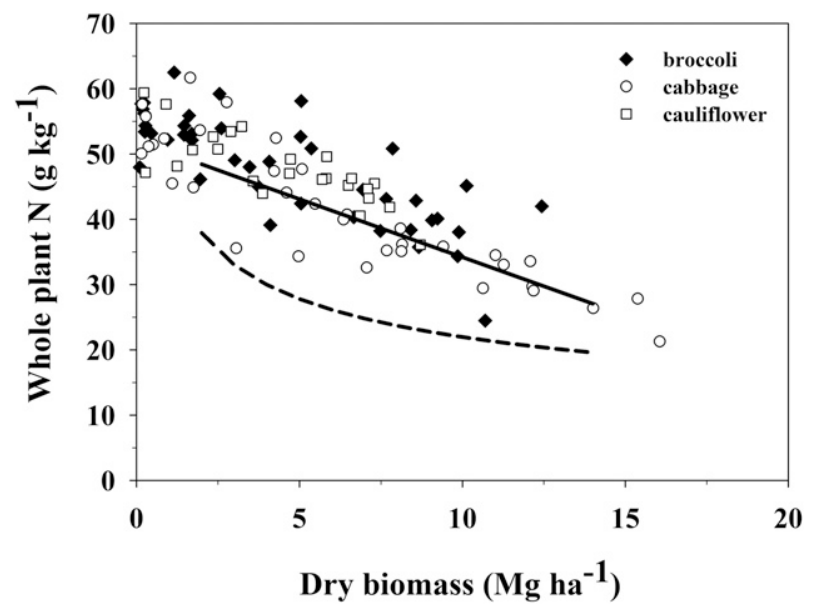

Fig. 2. Whole plant $\mathrm{N}$ concentration as a function of aboveground dry biomass; data from all sampling dates included. Observed values compared with critical $\mathrm{N}$ concentration models proposed by Greenwood et al. (1996; $N_{c}=52-1.78$ dry biomass, solid line) and Lemaire and Gastal (1997; $N_{c}=48$ dry biomass ${ }^{-0.34}$, dashed line).

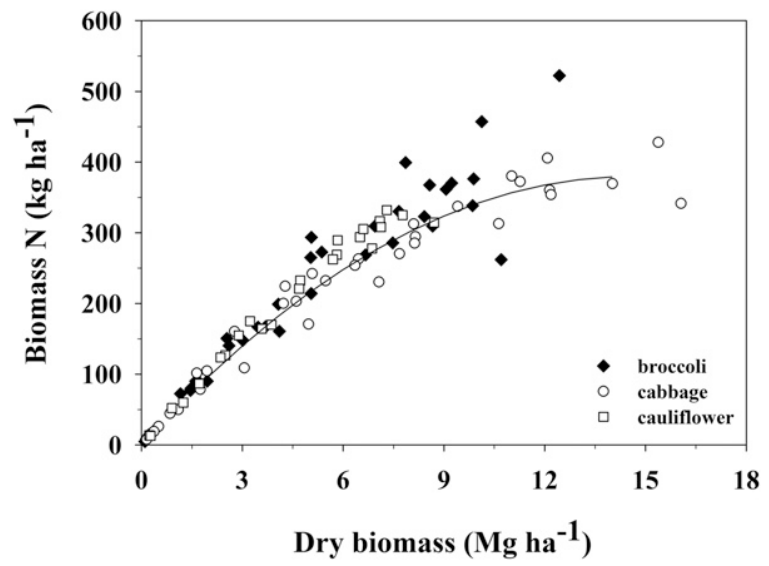

Fig. 3. Biomass $\mathrm{N}$ accumulation as a function of aboveground dry biomass; data from all sampling dates included. Observed values compared with critical $\mathrm{N}$ uptake ( $N_{\text {upt }}$, solid line) calculated from Greenwood et al. [1996; $N_{\text {upt }}=$ dry biomass $\times(52-1.78$ dry biomass $\left.)\right]$. 
fields (Fig. 3). Luxury $\mathrm{N}$ uptake was particularly evident in broccoli fields at harvest. At the mean level of aboveground biomass observed at harvest, $N_{\text {upt }}$ was 335 and $295 \mathrm{~kg} \cdot \mathrm{ha}^{-1}$ for broccoli and cauliflower, respectively.

Conversely, cabbage fields were often below the $N_{c}$ estimate of Greenwood et al. (1996), a phenomenon also reported for adequately fertilized cabbage by Riley and Guttormsen (1999). However, when compared with the general $N_{c}$ model for $C_{3}$ plants suggested by Lemaire and Gastal (1997; $N_{c}=$ 48 dry biomass ${ }^{-0.34}$ ), all cabbage fields also appeared to have been adequately supplied with $\mathrm{N}$ (Fig. 2). The higher biomass productivity in cabbage fields relative to broccoli, achieved in a shorter growing season, supported the conclusion that the cabbage fields were not $\mathrm{N}$ limited.

Rooting depth increased linearly throughout the growing season (Fig. 4). The slope of the regression relationship between root depth and time did not differ significantly among crop types $(P<0.22)$. Roots reached $\approx 1$-m depth by harvest. These results were similar to those of Greenwood et al. (1982) who reported that cauliflower rooting depth increased throughout the growing period, reaching at least $80-\mathrm{cm}$ depth by harvest. Thorup-Kristensen (2001) found that cabbage roots reached $1.25-\mathrm{m}$ depth by the end of the season. Root distribution at harvest showed a large majority of roots in the top $40 \mathrm{~cm}$ for all crops (Fig. 5). Across the five fields monitored, $72 \pm 3 \%$ (SE) of roots were observed in the top $40 \mathrm{~cm}$ of soil, with $90 \pm$ $2 \% \mathrm{SE}$ in the top $60 \mathrm{~cm}$. Similar root distribution by depth has been reported by Greenwood et al. (1982) and Rather et al. (2000).

SMN in the top $30 \mathrm{~cm}$ at the first biomass sampling (typically 4-5 weeks after seeding or transplanting) ranged from 2 to $95 \mathrm{mg} \cdot \mathrm{kg}^{-1}$, with a median of $18 \mathrm{mg} \cdot \mathrm{kg}^{-1}$ (Fig. 6). More than $90 \%$ of $\mathrm{SMN}$ was $\mathrm{NO}_{3}-\mathrm{N}$, a substantial portion of which was undoubtedly residual soil $\mathrm{NO}_{3}-\mathrm{N}$ carried over from previous crops. High residual soil $\mathrm{NO}_{3}-\mathrm{N}$ is a characteristic of this vegetable production system (Breschini and Hartz, 2002; Bottoms et al., 2012). There was no correlation between early-season SMN and the total $\mathrm{N}$ applied to the crop; however, this correlation may have been confounded by the fact that an $\mathrm{N}$ application had already been applied in some fields before the first soil sampling date. SMN at harvest declined to a median of $5 \mathrm{mg} \cdot \mathrm{kg}^{-1}$ in the top $30 \mathrm{~cm}$, and a median of $2 \mathrm{mg} \cdot \mathrm{kg}^{-1}$ in the 30 - to $60-\mathrm{cm}$ depth (data not shown). This suggested that cole crop production can be managed to leave minimal SMN in the rooting zone at harvest. Bottoms et al. (2012) documented that lettuce production in this region could be managed to have root zone SMN as low at $5 \mathrm{mg} \cdot \mathrm{kg}^{-1}$ without loss of crop productivity.

Across crops, irrigation applied averaged $>200 \%$ of estimated $\mathrm{ET}_{\mathrm{c}}$ (Fig. 7). Even assuming that the irrigation requirement would be $25 \%$ to $30 \%$ greater than $\mathrm{ET}_{\mathrm{c}}$ to account for irrigation system inefficiency, it was clear that excessive irrigation was applied in many fields. Irrigation during crop

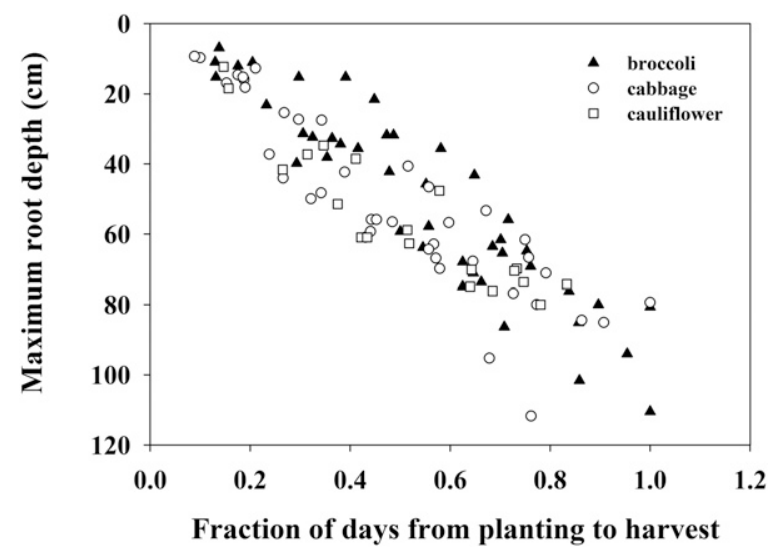

Fig. 4. Maximum rooting depth as a function of time after planting.

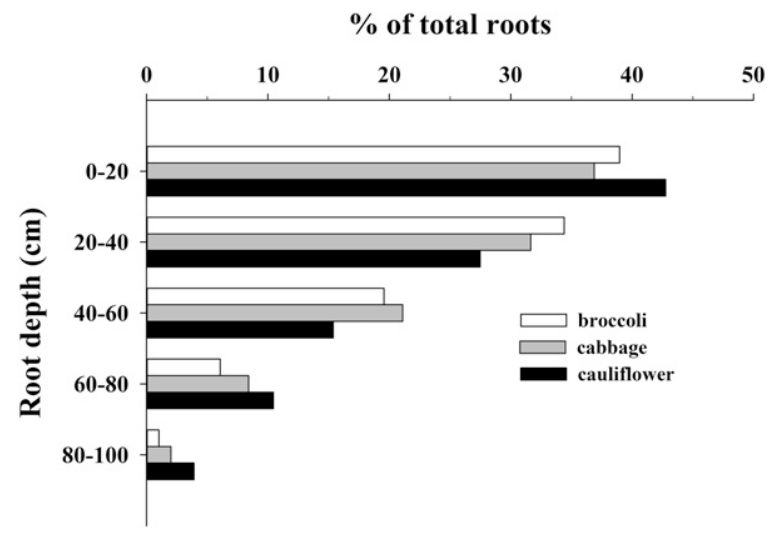

Fig. 5. Root distribution at harvest as a function of soil depth.

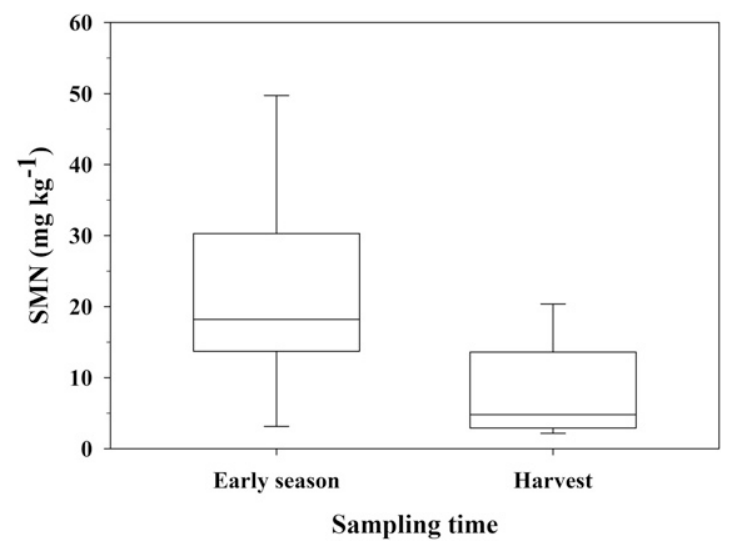

Fig. 6. Range of soil mineral N (SMN), 0- to 30-cm depth observed at the first biomass sampling and at harvest in all fields. The box encompasses the 25 th and 75 th percentile with the bar representing the median value; external bars indicate the 10th and 90th percentile.

establishment (the initial 2-3 weeks of the season) was particularly inefficient. To ensure a uniform plant stand growers frequently irrigated more than $\mathrm{ET}_{\mathrm{c}}$ to compensate for factors such as wind (which reduces the application uniformity of overhead sprinklers) and spatial variability in the waterholding capacity of soil. The combination of substantial leaching volume and high earlyseason soil $\mathrm{NO}_{3}-\mathrm{N}$ suggested the potential for significant $\mathrm{NO}_{3}-\mathrm{N}$ leaching during the crop establishment period. Precipitation was a minor influence, averaging $<1 \mathrm{~cm}$ in the monitored fields.

Substantial N mineralization from incorporated broccoli residue was observed in both fields monitored (Fig. 8). This was expected given the high residue $\mathrm{N}$ concentration (30 and $36 \mathrm{~g} \cdot \mathrm{kg}^{-1}$ in fields 1 and 2, respectively), and the large amount of residue $\mathrm{N}$ (220 and $289 \mathrm{~kg} \cdot \mathrm{ha}^{-1}$, respectively). An increase in SMN was also observed in the absence of residue incorporation, indicating substantial net soil $\mathrm{N}$ mineralization. SMN, 
which was $>80 \% \mathrm{NO}_{3}-\mathrm{N}$ on most sampling dates, declined sharply following significant rainfall; precipitation totals over the monitored period were 22 and $23 \mathrm{~cm}$ in fields 1 and 2 , respectively, close to the long-term averages in this area for this period. The sharp decline in SMN by the end of the monitoring period suggested the likelihood of large $\mathrm{NO}_{3}$ $\mathrm{N}$ leaching losses in both fields (Fig. 8).

These results have important implications for cole crop management. Given the similarity in patterns of growth, root development, and $\mathrm{N}$ uptake among crops, similar $\mathrm{N}$ fertilization practices would appear to be appropriate for all three crops. The justification for the use of substantially higher fertilizer $\mathrm{N}$ rates for cabbage and cauliflower than for broccoli was unclear. Despite a wide range of field configurations and plant populations, the pattern of $\mathrm{N}$ uptake among fields was quite consistent, and therefore predictable.

This study documented that cole crops have a high capacity to scavenge SMN. Across all monitored fields, aboveground biomass $\mathrm{N}$ was $115 \mathrm{~kg} \cdot \mathrm{ha}^{-1}$ greater than the seasonal $\mathrm{N}$ application rate, with individual fields exceeding $200 \mathrm{~kg} \cdot \mathrm{ha}^{-1}$. However, to take optimal advantage of this $\mathrm{N}$ scavenging ability, one must take into account the level of residual SMN when determining $\mathrm{N}$ fertilization requirements. The value of using residual SMN in determining $\mathrm{N}$ fertilizer requirements has been widely documented for vegetable production in general (Breschini

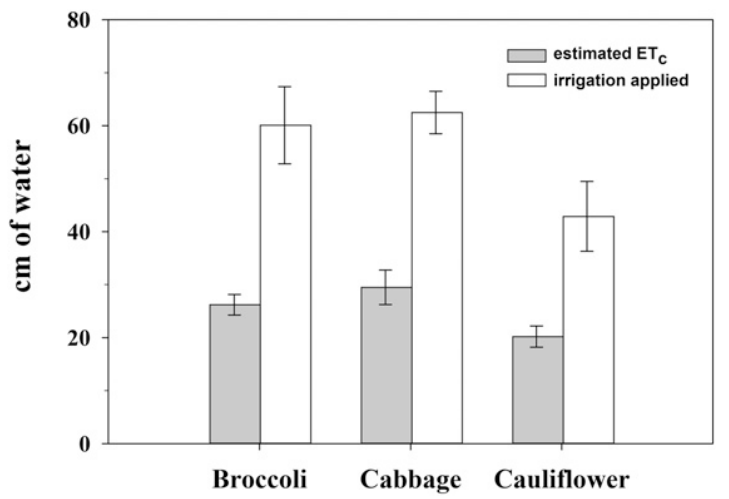

Fig. 7. Comparison of estimated crop evapotranspiration $\left(\mathrm{ET}_{\mathrm{c}}\right)$ with the irrigation volume applied; bars represent SE of measurement.

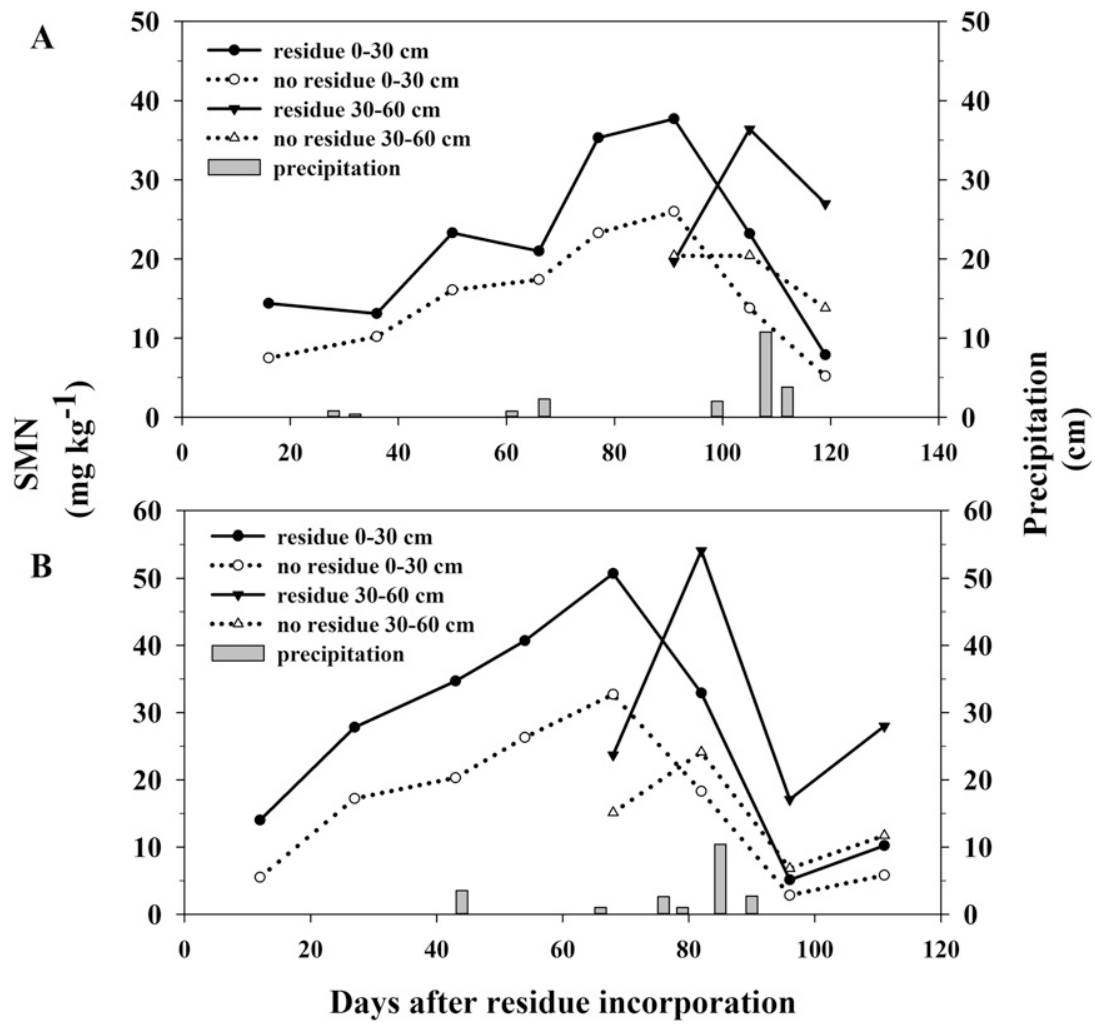

Fig. 8. Effect of broccoli residue incorporation on soil mineral N (SMN) concentration; no residue indicates the removal of aboveground residue before soil incorporation. Residue was incorporated on (A) 25 Aug. (field 1) or (B) 17 Sept. 2014 (field 2).

and Hartz, 2002; Hartz et al., 2000; Heckman et al., 1995; Krusekopf et al., 2002), and for cole crops in particular (Everaarts and van den Berg, 1996; Heckman et al., 2002; Zebarth et al., 1995). A common approach has been to use pre-sidedress soil $\mathrm{NO}_{3}-\mathrm{N}$ testing to determine sidedress $\mathrm{N}$ rate; reported response thresholds have varied from $16 \mathrm{mg} \cdot \mathrm{kg}^{-1}$ for tomatoes (Krusekopf et al., 2002) to 24 $\mathrm{mg} \cdot \mathrm{kg}^{-1}$ for cabbage (Heckman et al., 2002).

The most practical way to account for residual SMN depends on the field environment and management practices. In most rainfed, temperate cole crop production areas, a single SMN determination at or shortly after crop establishment may provide a good guide to seasonal $\mathrm{N}$ fertilizer requirements (Everaarts and van den Berg, 1996; Heckman et al., 2002; Zebarth et al., 1995). In such areas, it is uncommon for in-season precipitation to substantially exceed $\mathrm{ET}_{\mathrm{c}}$, so the in-season $\mathrm{NO}_{3}-\mathrm{N}$ leaching hazard is typically limited. This is undoubtedly why split $\mathrm{N}$ applications are often ineffective in increasing yield or $\mathrm{N}$ use efficiency in such production areas (Bowen et al., 1999; Everaarts, 1993).

In contrast, in irrigated production, the potential for in-season $\mathrm{NO}_{3}-\mathrm{N}$ leaching losses can be substantial. Although irrigation management in the monitored fields could unquestionably have been improved, there are practical limits to irrigation efficiency. Field-scale sprinkler systems seldom achieve a distribution uniformity $>80 \%$ (Little et al., 1993). Even in drip-irrigated culture, maximizing broccoli or cauliflower yield by the maintenance of low soil moisture tension may result in a large leaching fraction, and associated $\mathrm{N}$ loss (Thompson et al., 2000a, 2000b; Thompson et al., 2002a, 2002b).

In Salinas Valley vegetable production, there are often two or more in-season $\mathrm{N}$ applications. Soil $\mathrm{NO}_{3}-\mathrm{N}$ sampling before each scheduled application, and only applying enough $\mathrm{N}$ to bring soil up to the response threshold, has been shown to dramatically reduce seasonal $\mathrm{N}$ rates without endangering lettuce productivity (Bottoms et al., 2012; Breschini and Hartz, 2002). This approach should be applicable to cole crops as well. Although cole crop roots may eventually reach 1-m depth, confining soil $\mathrm{NO}_{3}-\mathrm{N}$ sampling to the top $30 \mathrm{~cm}$, at least during the first half of the growing season, seems prudent; later in the season, deeper sampling may be appropriate. The consistent pattern of crop $\mathrm{N}$ uptake provides a basis on which to adjust the timing and amount of late-season $\mathrm{N}$ application to draw down SMN by harvest.

Residue management presents a serious challenge to $\mathrm{N}$ efficiency in cole crop production. Both residue amount and $\mathrm{N}$ concentration are high, and the rapid mineralization of residue $\mathrm{N}$ observed here has been confirmed in other production environments (Chaves et al., 2007; Congreves and Van Eerd, 2015; De Neve et al., 2003; de Ruijter et al., 2010). Various methods to reduce $\mathrm{NO}_{3}$ $\mathrm{N}$ leaching potential after cole crop production have been proposed. The potential to immobilize residue $\mathrm{N}$ through the application 
of high $\mathrm{C} / \mathrm{N}$ organic materials has been demonstrated (Agneessens et al., 2015; Chaves et al., 2007; Congreves et al., 2013), but economic and logistical considerations make adoption of this approach unlikely. The use of cover crops to limit fallow-season $\mathrm{NO}_{3}-\mathrm{N}$ leaching loss has been widely studied. Although winter cover cropping has been shown to substantially reduce $\mathrm{NO}_{3}-\mathrm{N}$ leaching in Salinas Valley vegetable production (Wyland et al., 1996), cover crop usage remains uncommon. In addition to the direct costs involved, cover cropping can disrupt spring planting schedules, a serious issue in such an intensive production system. However, novel methods of cover cropping [low residue cover cropping, repeat mowing of cover crops, etc. (Brennan, 2016)] may help increase this important practice.

In summary, the $\mathrm{N}$ dynamics of broccoli, cabbage, and cauliflower production are quite similar. Crop N uptake may substantially exceed the $\mathrm{N}$ fertilization rate, but the small fraction of biomass $\mathrm{N}$ removed with the harvest typically results in a low PNB. Residual SMN differs widely among fields, and it should be taken into account when determining $\mathrm{N}$ fertilization requirement. Low irrigation efficiency contributes to in-season nitrate leaching. In the absence of a remediation practice such as cover cropping, rapid $\mathrm{N}$ mineralization from fall-incorporated cole crop residue contributes significantly to the nitrate leaching risk during the winter fallow period.

\section{Literature Cited}

Agneessens, L., J. Viaene, T. Vanden Nest, B. Vandecasteele, and S. De Neve. 2015. Effect of ensilaged vegetable crop residue amendments on soil carbon and nitrogen dynamics. Scientia Hort. 192:311-319.

Bakker, C.J., C.J. Swanton, and A.W. McKeown. 2009a. Broccoli growth in response to increasing rates of pre-plant nitrogen. I. Yield and quality. Can. J. Plant Sci. 89:527-537.

Bakker, C.J., C.J. Swanton, and A.W. McKeown. $2009 \mathrm{~b}$. Broccoli growth in response to increasing rates of pre-plant nitrogen. II. Dry matter and nitrogen accumulation. Can. J. Plant Sci. 89:539-548.

Bottoms, T.G., R.F. Smith, M.D. Cahn, and T.K. Hartz. 2012. Nitrogen requirements and N status determination of lettuce. HortScience 47:1768-1774.

Bowen, P.A., B.J. Zebarth, and P.M.A. Toivonen. 1999. Dynamics of nitrogen and dry-matter partitioning and accumulation in broccoli (Brassica oleracea var. italica) in relation to extractable soil inorganic nitrogen. Can. J. Plant Sci. 79:277-286.

Brennan, E.B. 2016. Can we grow organic or conventional vegetables sustainably without cover crops? HortTechnology 26:(In press).

Breschini, S.J. and T.K. Hartz. 2002. Presidedress soil nitrate testing reduces nitrogen fertilizer use and nitrate leaching hazard in lettuce production. HortScience 37:1061-1064.

Chaves, B., S. De Neve, P. Boeckx, O. Van Cleemput, and G. Hofman. 2007. Manipulating nitrogen release from nitrogen-rich crop residues using organic wastes under field conditions. Soil Sci. Soc. Amer. J. 71:1240-1250.

Congreves, K.A. and L.L. Van Eerd. 2015. Nitrogen cycling and management in intensive horticultural systems. Nutr. Cycl. Agroecosyst. 102:299-318.

Congreves, K.A., R.J. Vyn, and L.L. Van Eerd. 2013. Evaluation of post-harvest organic carbon amendments as a strategy to minimize nitrogen losses in cole crop production. Agronomy 3:181-199.

Cutcliffe, J.A. and D.C. Munro. 1976. Effects of nitrogen, phosphorus and potassium on yield and maturity of cauliflower. Can. J. Plant Sci. 65:127-131.

De Neve, S. and G. Hoffman. 1996. Modelling N mineralization of vegetable crop residues during laboratory incubations. Soil Biol. Biochem. 28:1451-1457.

De Neve, S., I. Dieltjens, E. Moreels, and G. Hoffman. 2003. Measured and simulated nitrate leaching on an organic and a conventional mixed farm. Biol. Agr. Hort. 21:217-229.

de Ruijter, F.J., H.F.M. ten Berg, and A.L. Smit. 2010 The fate of nitrogen from crop residues of broccoli, leek and sugarbeet. Acta Hort. 852:157-161.

Everaarts, A.P. 1993. Strategies to improve the efficiency of nitrogen fertilizer use in the cultivation of Brassica vegetables. Acta Hort. 339:161-173.

Everaarts, A.P. 2000. Nitrogen balance during growth of cauliflower. Scientia Hort. 83:173-186.

Everaarts, A.P. and W. van den Berg. 1996. A comparison of three nitrogen response models for cauliflower. Acta Hort. 428:171-179.

Gallardo, M., R.L. Snyder, K. Schulbach, and L.E. Jackson. 1996. Crop growth and water use model for lettuce. J. Irrig. Drain. Eng. 122:354-359.

Greenwood, D.J., A. Gerwitz, D.A. Stone, and A. Barnes. 1982. Root development of vegetable crops. Plant Soil 68:75-96.

Greenwood, D.J., C. Rahn, A. Draycott, L.V. Vaidyanathan, and C. Paterson. 1996. Modelling and measurement of the effects of fertilizer- $\mathrm{N}$ and crop residue incorporation on $\mathrm{N}$-dynamics in vegetable cropping. Soil Use Mgt. 12:13-24.

Harter, T. 2015. California's agricultural regions gear up to actively manage groundwater use and protection. Calif. Agr. 69:193-201.

Hartz, T.K., W.E. Bendixen, and L. Wierdsma. 2000. The value of presidedress soil nitrate testing as a nitrogen management tool in irrigated vegetable production. HortScience 35:651-656.

Heckman, J.R., W.T. Hlubik, D.J. Prostak, and J.W. Patterson. 1995. Pre-sidedress soil nitrate test for sweet corn. HortScience 30:1033-1036.

Heckman, J.R., T. Morris, J.T. Sims, J.B. Sieczka, U. Krogmann, P. Nitzsche, and R. Ashley. 2002. Pre-sidedress soil nitrate test is effective for fall cabbage. HortScience 37:113-117.

Hofer, S. 2003. Determination of ammonia (salicylate) in $2 \mathrm{M} \mathrm{KCl}$ soil extracts by flow injection analysis. QuikChem Method 12-107-06-2-A. Lachat Instruments, Loveland, CO.

Jackson, L.E., L.J. Stivers, B.T. Warden, and K.K Tanji. 1994. Crop nitrogen utilization and soil nitrate loss in a lettuce field. Fert. Res. 37:93-105.

Johnson, L., M. Cahn, F. Martin, S. Benzen, and B. Farrara. 2016. Evapotranspiration-based irrigation scheduling of head lettuce and broccoli. HortScience 51:935-940.

Kahn, B.A., P.G. Shilling, G.H. Brusewitz, and R.W. McNew. 1991. Force to shear the stalk, stalk diameter and yield of broccoli in response to nitrogen fertilization and within-row spacing. J. Amer. Soc. Hort. Sci. 116:222-227.

Knepel, K. 2003. Determination of nitrate in $2 \mathrm{M}$ $\mathrm{KCl}$ soil extracts by flow injection analysis. QuikChem Method 12-107-04-1-B. Lachat Instruments, Loveland, $\mathrm{CO}$.

Krusekopf, H.H., J.P. Mitchell, T.K. Hartz, D.M. May, E.M. Miyao, and M.D. Cahn. 2002.
Pre-sidedress soil nitrate testing identifies processing tomato fields not requiring sidedress $\mathrm{N}$ fertilizer. HortScience 37:520-524.

Lemaire, G. and F. Gastal. 1997. N uptake and distribution in plant canopies, p. 3-41. In: G. Lemaire (ed.). Diagnosis of nitrogen status in crops. Springer-Verlag, Berlin, Germany.

Little, G.E., D.J. Hills, and B.R. Hanson. 1993. Uniformity in pressurized irrigation systems depends on design, installation. Calif. Agr. 47(3):18-21

Rather, K., M.K. Schenk, A.P. Everaarts, and S. Vethman. 2000. Rooting pattern and nitrogen uptake of three cauliflower (Brassica olearaced var. botrytis) $\mathrm{F}_{1}$-hybrids. J. Plant Nutr. Soil Sci. $163: 467-474$

Riley, H. and G. Guttormsen. 1999. Alternative equations for critical N-concentration in cabbage. Acta Hort. 506:123-128.

Rosenstock, T.S., D. Liptzin, K. Dzurella, A. FryjoffHung, A. Hollander, V. Jensen, A. King, G. Kourakos, A. McNally, G.S. Pettygrove, J. Quinn, J.H. Viers, T.P. Tomich, and T. Harter. 2014. Agriculture's contribution to nitrate contamination of California groundwater. J. Environ. Qual. 43:895-907.

Smittle, D.A., W.L. Dickens, and J.R. Stansell. 1994. Irrigation regimes affect cabbage water use and yield. J. Amer. Soc. Hort. Sci. 119:20-23

Sorensen, J.N. 1999. Nitrogen effects on vegetable crop production and chemical composition. Acta Hort. 506:41-49.

Thompson, T.L., T.A. Doerge, and R.E. Godin. 2000a. Nitrogen and water interactions in subsurface drip-irrigated cauliflower: I. Plant response. Soil Sci. Soc. Amer. J. 64:406-411.

Thompson, T.L., T.A. Doerge, and R.E. Godin. $2000 \mathrm{~b}$. Nitrogen and water interactions in subsurface drip-irrigated cauliflower: II. Agronomic, economic and environmental outcomes. Soil Sci. Soc. Amer. J. 64:412-418

Thompson, T.L., T.A. Doerge, and R.E. Godin. 2002a. Subsurface drip irrigation and fertigation of broccoli: I. Yield, quality and nitrogen uptake. Soil Sci. Soc. Amer. J. 66:186-192.

Thompson, T.L., T.A. Doerge, and R.E. Godin. $2002 \mathrm{~b}$. Subsurface drip irrigation and fertigation of broccoli: II. Agronomic, economic and environmental outcomes. Soil Sci. Soc. Amer. J. 66:178-185.

Thorup-Kristensen, K. 2001. Root growth and soil nitrogen depletion by onion, lettuce, early cabbage and carrot. Acta Hort. 563:201-206.

Vagen, I.M., A.O. Skjelvag, and H. Bonesmo. 2004. Growth analysis of broccoli in relation to fertilizer nitrogen application. J. Hort. Sci. Biotechnol. 79:484-492.

Willcutts, J.F., A.R. Overman, G.J. Hochmuth, D.J. Cantliffe, and P. Soundy. 1998. A comparison of three mathematical models of response to applied nitrogen: A case study using lettuce. HortScience 33:833-836.

Wyland, L.J., L.E. Jackson, W.E. Chaney, K. Klonsky, S.T. Koike, and B. Kimple. 1996. Winter cover crops in a vegetable cropping system: Impacts on nitrate leaching, soil water, crop yield, pests and management costs. Agr. Ecosyst. Environ. 59:1-17.

Zebarth, B.J., P.A. Bowen, and P.M. Toivonen. 1995. Influence of nitrogen fertilization on broccoli yield, nitrogen accumulation and apparent fertilizer-nitrogen recovery. Can. J. Plant Sci. 75:717-725.

Zebarth, B.J., S. Freyman, and C.G. Kowalenko. 1991. Influence of nitrogen fertilization on cabbage yield, head nitrogen content and extractable soil inorganic nitrogen at harvest. Can. J. Plant Sci. 71:1275-1280. 